\title{
Effect of Building Envelope Materials on Indoor Air Quality in Low Energy Test Houses
}

\author{
Inga Apine, Liana Orola, and Andris Jakovics
}

\begin{abstract}
Five low energy test houses were investigated in order to study an effect of chemical and biological pollution on indoor air quality. It has been found that TVOC levels depend on building and finishing materials used in those houses. Ventilation is the most effective way to diminish TVOC concentrations in indoor air. To evaluate fungal contamination air and surface analyses were performed. Only the presence of Aspargillus and Penicillium indicated fungal pollution in air samples while surface analyses gave more complete information. The results showed that at standard ventilation conditions use of building materials with increased initial moisture content can cause significant mould development.
\end{abstract}

Index Terms - Indoor air quality, building materials, fungi, low energy house, volatile organic compounds.

\section{INTRODUCTION}

Nowadays, requirement for energy saving and improving energy efficiency leads to increasing focus on air-tightness and controlled ventilation of buildings all over the world. Accordingly, there is a strong necessity to ensure optimum conditions for indoor environment where people spend most of their lives [1]. Indoor air quality is affected not only by physical factors such as temperature and humidity but also by chemical and biological pollution. Volatile organic compounds (VOCs) are chemical pollutants common in indoor environment. Important source of VOCs are building and finishing materials [2]. Levels of volatile organic compounds in newbuilds are often several times higher than VOCs in established buildings [3], [4]. The initial concentrations of VOCs in new buildings tend to decrease dramatically after one year and level with concentrations in older buildings [4]. Proper ventilation is an important and easily accessible tool to reduce chemical pollution and improve indoor air quality [5].

Bioaerosol is an integral part of ambient air. It consists of different types of organic particles: bacteria, fungi, viruses, pollen, house dust mites and various non-living particles of biological origin [6]. Fungi are ubiquitous organisms that play a fundamental role as saprotrophs in a natural recycling

Manuscript received on September 29, 2014; revised March 12, 2015. This research is done with financial support of ESF, the project carried by University of Latvia, No. 2013/0027/1DP/1.1.1.2.0/13/APIA/VIAA/007.

Inga Apine is with the Botanical Garden, University of Latvia, 2 Kandavas Str., Riga, LV-1083, Latvia (e-mail: inga. apine@lu.lv).

Liana Orola is with the Faculty of Chemistry, University of Latvia, 48 Kr. Valdemāra Str., Riga, LV-1013, Latvia (e-mail: liana.orola@lu.lv).

Andris Jakovics is with the Faculty of Physics and Mathematics, University of Latvia, 8 Zellı Str., Riga LV-1002, Latvia (e-mail: andris.jakovics@lu.lv). process by decomposing organic materials. They are an important part of bioaerosol and can cause serious harm not only to different materials but also to human health if the environment supports proliferation of these microorganisms. The air micoflora includes several components: spores, hyphal fragments as well as diverse fungal metabolites (mycotoxins and volatile organic compounds) - all these can be involved in adverse health effects [7].

The presence of fungi in indoor environment depends on many factors such as microbial content of outdoor air, ventilation system (natural, mechanical or mixed-mode), building maintenance and indoor microclimate. Although the key factor for mould formation is a suitable humidity level it is also affected by interaction of humidity, temperature and properties of building materials [1], [8]. It is found that the optimal relative humidity $(\mathrm{RH})$ level for human health is $40-60 \%$ at room temperature. Meanwhile the established critical level for fungal growth on indoor surfaces is $\mathrm{RH}>75 \%$ [9], [10]. Excessive indoor humidity can be caused by several factors: natural disaster, construction shortcomings and improper maintenance of buildings as well as initial moisture content of materials employed [11], [12]. Aerated concretes are such materials with high original moisture content. The use of mortar for bonding ceramic blocks and/or plaster as interior finishing material cause rising of moisture content in wall elements and indoor environment, too. On the other hand, properly prepared wooden structural elements can serve as an opposite example [13]. One may observe an increasing influence of initial humidity levels in structural wall elements on indoor environment. It is determined by faster construction processes caused by economic factors [12].

Obviously, the choice of building envelope materials can directly affect the different components of indoor air quality. Nowadays the high demand for energy saving and optimal indoor microclimate requires testing of various building materials and their composition. Consequently, development of innovative building materials and their applications should be supported.

The aim of the present research is to study the effect of different building envelope materials on chemical and fungal pollution of indoor environment in small test buildings with similar heat transmittance levels, indoor temperature and ventilation, located in similar outdoor circumstances.

\section{MATERIALS AND METHODS}

\section{A. Test Houses}

The monitored test houses with inner dimensions 3 $m \times 3 m \times 3 m$ were located in the urban area of Riga, Latvia. The 
selected location was the territory of University Botanical Garden; all five houses were arranged at an equal angle towards the sun. Main characteristics of external building walls are presented in Table I. Roof, floor, doors and windows of all houses were similar.

For all types of exterior wall structures U-value equals 0.16
$\mathrm{W} \mathrm{m} \mathrm{m}^{-2} \mathrm{~K}^{-1}$. Building design provides solutions for elimination of thermal bridges. Constant air exchange rate of $0.45 \mathrm{~h}^{-1}$ is provided by Ururu Sarara air-air heat pump (Daikin, model FTX28E + RXR28E) equipped with air purification filters. Detailed information on the project is summarized in [14]. The houses were completed at the beginning of 2013 .

TABLE I: MAIN CHARACTERISTICS OF EXTERNAL WALlS OF TEST HOUSES INVESTIGATED IN THIS STUDY

\begin{tabular}{|c|c|c|c|c|c|}
\hline \multirow{3}{*}{ Characteristics } & \multicolumn{5}{|c|}{ Test house } \\
\hline & \multicolumn{3}{|c|}{ Heavyweight } & \multicolumn{2}{|c|}{ Lightweight } \\
\hline & AER & CER & EXP & PLY & LOG \\
\hline Construction type & $\begin{array}{l}\text { Aerated concrete } \\
\text { blocks }\end{array}$ & Aerated clay blocks & $\begin{array}{c}\text { Aerated clay blocks with } \\
\text { insulation (polystyrene) fillings }\end{array}$ & Plywood panels & Wooden log \\
\hline Insulation material & Stone wool & Stone wool & - & Stone wool & Stone wool \\
\hline Interior finishing & & & -cement plaster & & Decorative wooden log \\
\hline Ventilation system & & & Mechanical supply and exhaust & & \\
\hline
\end{tabular}

\section{B. Total Volatile Organic Compounds Measurement}

Concentrations of total volatile organic compounds (TVOC) were measured using photoacoustic gas monitor INNOVA 1412i (LumaSense Technologies, Denmark). The monitor was equipped with optical filter with a detection limit of $0.05 \mathrm{ppm}$ TVOC. Measurements were performed continuously for $1 \mathrm{~h}$ with a sample integration time of $20 \mathrm{~s}$ for each test house. Before taking measurements photoacoustic gas monitor was allowed to suck ambient air for about $10 \mathrm{~min}$ until readings of TVOC stabilized.

\section{Microbiological Analyses}

Monitoring of indoor temperature and relative humidity was started some months after the completion of buildings in spring, 2013. Information was received from a sensor (Sensirion SHT75) located at the height of $1.1 \mathrm{~m}$ and at a distance of $0.1 \mathrm{~m}$ from wall.

In test buildings an investigation of fungal pollution was performed from February till June, 2014. At first, inspection of rooms was carried out to identify the presence of visible moulded areas. Both air and surface samples were taken to determine the composition and concentration of viable fungal propagules.

Air samples were acquired using sedimentation plate method once per month. Total time period of microbiological study was 5 months. For each measurement six open Petri plates filled with $2 \%$ malt extract agar (MEA) were exposed for $2 \mathrm{~h}$. The plates were located in a similar way in each house: approximately $1 \mathrm{~m}$ above floor, $1 \mathrm{~m}$ away from walls. Samples of outdoor air were taken simultaneously to evaluate background level of fungi and to calculate indoor/outdoor fungal concentration ratio (I/O). These samples were collected at a height of $1.5 \mathrm{~m}$ and at a distance of 3-4 m from wall using shorter exposition time $\left(0.5^{-1} \mathrm{~h}\right)$ to prevent overloading of plate surfaces. The number of fungal

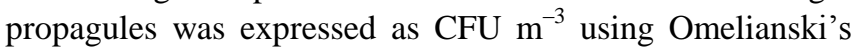
equation for recalculation:

$$
C F U / \mathrm{m}^{3}=a \cdot 10000 / p \cdot t \cdot 0.2,
$$

where:

$a$ : number of colonies on Petri plate,

$p$ : surface of Petri plate $\left(\mathrm{cm}^{2}\right)$,

$t$ : Petri plate exposure time $(\min )$ [15].
Surface samples were obtained using a swab method. The samples were taken from both visible moulded areas or risk zones (in rooms without visible mould infestation) and from so-called control areas. Control areas were chosen 1 to $1.5 \mathrm{~m}$ away from moulded or risk zones. In order to prepare one sample two moistened cotton swabs were used to wipe $20 \mathrm{~cm}^{2}$ of wall surface. These swabs were placed in vials containing $2 \mathrm{ml}$ of sterile distilled water. Solutions of the samples from visibly moulded areas required additional dilution from $10^{-2}$ to $10^{-5}$. One hundred $\mu \mathrm{l}$ of suspension was plated on Petri plates with $2 \%$ MEA in at least four replications.

The plates with air and surface samples were incubated at 20-23 ${ }^{\circ} \mathrm{C}$ for $10-14$ days. Filamentous fungi were identified to genera or species level using macro- and micromorphological traits.

Statistical differences among the samples were tested with the Wilcoxon rank test. Pearson's correlation coefficients were calculated to examine the relation between mould development and indoor RH level.

\section{RESULTS AND DISCUSSION}

\section{A. Total Volatile Organic Compounds}

In this study TVOC was used to describe chemical pollution in test houses. TVOC monitoring was performed under two air exchange rates: $0.45 \mathrm{~h}^{-1}$ and $0.8 \mathrm{~h}^{-1}$. Mean values and standard deviations of these measurements are summarized in Table II.

TABLE II: TVOC CONCENTRATIONS IN INDOOR AIR OF TEST HOUSES WITH DIFFERENT AIR EXCHANGE RATES

\begin{tabular}{ccc}
\hline \hline \multirow{2}{*}{ Test house } & \multicolumn{2}{c}{ TVOC concentration $\left(\mathrm{mg} \mathrm{m}^{-3}\right)$} \\
& Air exchange rate $0.45 \mathrm{~h}^{-1}$ & Air exchange rate $0.8 \mathrm{~h}^{-1}$ \\
\hline AER & $4.0 \pm 0.3$ & $1.9 \pm 0.1$ \\
CER & $4.0 \pm 0.3$ & $3.0 \pm 0.1$ \\
EXP & $5.7 \pm 0.2$ & $3.2 \pm 0.2$ \\
LOG & $13.1 \pm 0.4$ & $5.2 \pm 0.1$ \\
PLY & $5.5 \pm 0.1$ & $3.1 \pm 0.1$ \\
\hline \hline
\end{tabular}

As shown by these results, TVOC concentrations in indoor air depend on test house type. Mean concentrations were relatively low in AER, CER, PLY, EXP test houses and high in LOG house. This exception can be caused by specific varnish applied on decorative wooden logs in interior. 
Varnish contains various volatile organic compounds [2], [3] that may increase TVOC level in indoor air. Comparison of TVOC levels in AER, CER, PLY, and EXP test houses revealed that measured concentrations were lower in the first two houses. This observation may be explained by mainly inorganic origin of construction materials used in these test houses.

Air exchange rate is another aspect affecting TVOC levels in the studied houses (Table II). Approximately twice higher air exchange rate decreases concentration of TVOC from 1.3 (CER house) up to 2.5 (LOG house) times. In other test houses (PLY, AER, EXP) TVOC level was reduced approximately by one half. This observation is in accordance with results obtained by other authors [4].

\section{B. Assessment of Fungal Pollution}

Microbiological contamination in test houses was evaluated with respect to temperature and relative humidity. During heating season (from October till April) the temperature was maintained $18.7 \pm 0.8^{\circ} \mathrm{C}$ while in summer it was slightly higher $-22.5 \pm 2.0^{\circ} \mathrm{C}$. In well ventilated houses measurements of air RH (Fig. 1) reflected mainly the initial moisture content of building materials. Compared to summer season the overall RH was lower during heating season. Detailed information regarding $\mathrm{RH}$ in envelope structures has been presented in previous literature [13].

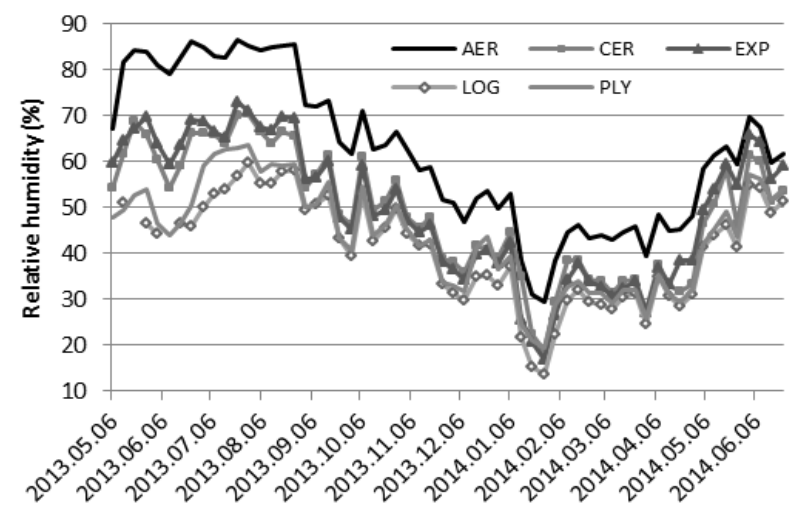

Fig. 1. Indoor air relative humidity in test houses.

Microbiological investigations were started approximately one year after the completion of buildings when $\mathrm{RH}$ was lower than $50 \%$ in all houses. Visible mould growth was observed only in AER building with the highest values of RH. In this building mouldy surfaces were found mainly along the lower perimeter of walls at a height of up to $10-15 \mathrm{~cm}$, in corners - up to $20-25 \mathrm{~cm}$. Some smaller areas of mould were identified in upper corners of the room. Altogether, the visible mould growth in AER building covered the area of approximately $0.8 \mathrm{~m}^{2}$. Apparently, the observed fungal pollution had emerged shortly after building's completion when indoor RH had been exceeding $85 \%$ for more than three months.

The results obtained from surface samples are displayed in Table III. In AER building the samples collected from moulded area showed significant contamination. In total eight genera of filamentous fungi and some yeasts were identified. Four genera were recognized in more than $50 \%$ of samples: Acremonium, Verticillium tenerum, Penicillium, Aspargillus.
In control areas without visible mould growth only Penicillium and Aspargillus made some significant contamination. In other heavyweight buildings (CER, EXP) with quite similar $\mathrm{RH}$ values visible mouldy patches were not observed and control areas did not display any significant fungal infestation. However, samples taken from potential risk areas (e.g., lower corners of rooms) showed considerable amount of some fungi: Cladosporium, Geomyces, Penicillium and Aspargillus. Nevertheless, contamination level was essentially lower compared to AER house. All fungal genera detected in these test houses were common for buildings with mould problems [16]-[18]. Furthermore, Ulocladium and Stachybotrys chartarum were also identified in individual samples acquired from heavyweight buildings. This indicated that the particular conditions were sufficient for the development of not only xerophilic (Penicillium, Aspargillus) and mesophilic (Cladosporium, Verticillium etc.) moulds but also of hydrophilic fungi - Acremonium, Ulocladium and even Stachybotrys chartarum. It has been noted that $S$. chartarum is typical only for long-term moisture damage [7], [8], [19]. Apparently, in risk areas of AER, CER and EXP houses humidity on surfaces had been reaching $90 \%$ for a certain period of time. Although in CER and EXP houses prevailing indoor air RH did not exceed $70 \%$, excess humidity on surfaces could facilitate growth of hydrophilic species. The obtained results confirm that indoor air $\mathrm{RH}$ higher than $60 \%$ can already promote fungal growth [20].

In lightweight buildings (LOG, PLY) observed RH values were below $60 \%$ threshold. Only in PLY house RH reached 60-63\% during July. No considerable fungal pollution in surface samples taken from risk and control areas was identified in these two houses.

A correlation ( $r=0.88 ; P<0.001)$ was found between indoor $\mathrm{RH}$ and fungal density on wall surfaces. Lime-cement plasters had been used as finishing materials in all test buildings with fungal pollution. This indicates that at favourable conditions plaster might serve as a substrate for fungal development right after building's completion. Besides, plaster is often supplemented by different organic additives prone to promote growth of microorganisms as well [8].

The results obtained from air samples are summarized in Table IV. Air exchange in test houses was provided by conditioners thus minimizing the influence of outdoor air. Aeromycoflora level in outdoor air was typical for temperate climate zone [7], [21]. It was characterized by seasonal increase of total fungi concentration from $260 \pm 33 \mathrm{CFU} \mathrm{m}^{-3}$ in February to $2958 \pm 285 \mathrm{CFU} \mathrm{m}^{-3}$ in June. The concentration of predominant Cladosporium increased from 10\% in February to $80 \%$ in June. According to these results, the very low level of calculated indoor/outdoor (I/O) ratio (Table IV) indicated, first, that influence of outdoor air was minimized and, second, that the determined airborne fungi concentration was low in all test houses in general

In lightweight construction buildings (LOG, PLY) the total mycoflora concentration was 30 and $33 \mathrm{CFU} \mathrm{m} \mathrm{m}^{-3}$, respectively. Concentrations were higher in heavyweight buildings. Fungi concentration was close to $50 \mathrm{CFU} \mathrm{\textrm {m } ^ { - 3 }}$ in houses with slight fungal contamination (CER and EXP) and 


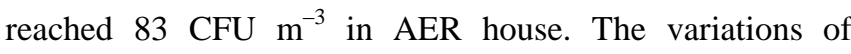
mycoflora arose mainly from significant increase in two typical indoor moulds - Aspargillus and Penicillium [18], [22] in test buildings with higher RH. Strong correlations were found between humidity level and total fungal concentrations in indoor air $(r=0.97 ; P<0.001)$ as well as between humidity level and the sum of Aspargillus and Penicillium $(r=0.95, \quad P<0.001)$. Several other fungi
(Cladosporium, Alternaria, Aureobasidium, Geotrichum, Zygorhynchus) were detected in all test buildings at similar levels. It could be attributed to the outdoor air influence as these genera were common in soil and different plant materials [17], [23]. The regular (although insignificant) presence of Penicillium in PLY building air samples might indicate some fungal growth on plaster apparently caused by increase of RH over $60 \%$.

TABle III: Culturable Fungal Propagule Density (CFU CM${ }^{-2}$ ) and Distribution Frequency (\%) Detected in SuRface Samples of Test BUILDINGS

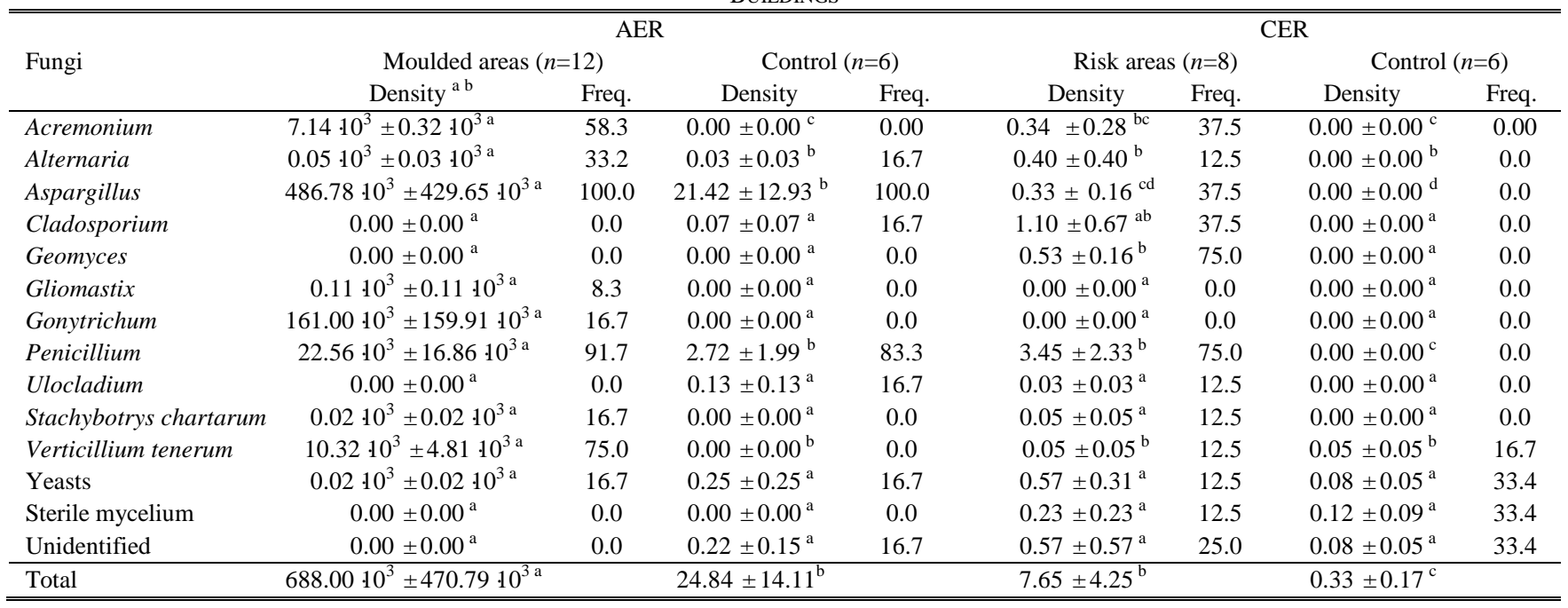

\begin{tabular}{|c|c|c|c|c|c|c|c|c|c|c|c|}
\hline \multirow{3}{*}{ Fungi } & \multicolumn{4}{|c|}{ EXP } & \multicolumn{4}{|c|}{ LOG } & \multicolumn{3}{|c|}{ PLY } \\
\hline & \multicolumn{2}{|c|}{ Risk areas $(n=8)$} & \multicolumn{2}{|c|}{ Control $(n=6)$} & \multicolumn{2}{|c|}{ Risk areas $(n=8)$} & \multicolumn{2}{|c|}{ Control $(n=6)$} & \multicolumn{2}{|c|}{ Risk areas $(n=8)$} & Control $(n=6)$ \\
\hline & Density & Freq. & Density & Freq. & Density & Freq. & Density & Freq. & Density & Freq. & Density \\
\hline Acremonium & $0.00 \pm 0.00^{\mathrm{c}}$ & 0.0 & $0.00 \pm 0.00^{\mathrm{c}}$ & 0.0 & $0.00 \pm 0.00^{\mathrm{c}}$ & 0.0 & $0.00 \pm 0.00^{\mathrm{c}}$ & 0.0 & $0.00 \pm 0.00^{\mathrm{c}}$ & 0.0 & $0.00 \pm 0.00^{\mathrm{c}} \quad 0.0$ \\
\hline Alternaria & $0.03 \pm 0.03^{b}$ & 12.5 & $0.00 \pm 0.00^{\mathrm{b}}$ & 0.0 & $0.04 \pm 0.04^{b}$ & 12.5 & $0.00 \pm 0.00^{b}$ & 0.0 & $0.03 \pm 0.03^{b}$ & 12.5 & $0.00 \pm 0.00^{\mathrm{b}} \quad 0.0$ \\
\hline Aspargillus & $0.73 \pm 0.29^{c}$ & 87.5 & $0.00 \pm 0.00^{\mathrm{d}}$ & 0.0 & $0.00 \pm 0.00^{\mathrm{d}}$ & 0.0 & $0.00 \pm 0.00^{\mathrm{d}}$ & 0.0 & $0.09 \pm 0.07^{\mathrm{d}}$ & 25.0 & $0.00 \pm 0.00^{\mathrm{d}} \quad 0.0$ \\
\hline Cladosporium & $0.54 \pm 0.26^{b}$ & 50.0 & $0.00 \pm 0.00^{\mathrm{a}}$ & 0.0 & $0.00 \pm 0.00^{\mathrm{a}}$ & 0.0 & $0.00 \pm 0.00^{\mathrm{a}}$ & 0.0 & $0.09 \pm 0.07^{\mathrm{a}}$ & 25.0 & $0.04 \pm 0.04^{\mathrm{a}} 16.7$ \\
\hline Geomyces & $0.85 \pm 0.57^{b}$ & 62.5 & $0.00 \pm 0.00^{\mathrm{a}}$ & 0.0 & $0.00 \pm 0.00^{\mathrm{a}}$ & 0.0 & $0.00 \pm 0.00^{\mathrm{a}}$ & 0.0 & $0.00 \pm 0.00^{\mathrm{a}}$ & 0.0 & $0.00 \pm 0.00^{\mathrm{a}} \quad 0.0$ \\
\hline Gliomastix & $0.00 \pm 0.00^{\mathrm{a}}$ & 0.0 & $0.00 \pm 0.00^{\mathrm{a}}$ & 0.0 & $0.00 \pm 0.00^{\mathrm{a}}$ & 0.0 & $0.00 \pm 0.00^{\mathrm{a}}$ & 0.0 & $0.00 \pm 0.00^{\mathrm{a}}$ & 0.0 & $0.00 \pm 0.00^{\mathrm{a}} \quad 0.0$ \\
\hline Gonytrichum & $0.00 \pm 0.00^{\mathrm{a}}$ & 0.0 & $0.00 \pm 0.00^{\mathrm{a}}$ & 0.0 & $0.00 \pm 0.00^{\mathrm{a}}$ & 0.0 & $0.00 \pm 0.00^{\mathrm{a}}$ & 0.0 & $0.00 \pm 0.00^{\mathrm{a}}$ & 0.0 & $0.00 \pm 0.00^{\mathrm{a}} \quad 0.0$ \\
\hline Penicillium & $0.70 \pm 0.23^{b}$ & 75.0 & $0.04 \pm 0.04^{\mathrm{c}}$ & 0.0 & $0.04 \pm 0.04^{\mathrm{c}}$ & 12.5 & $0.04 \pm 0.04^{\mathrm{c}}$ & 16.7 & $0.09 \pm 0.04^{\mathrm{c}}$ & 25.0 & $0.04 \pm 0.04^{\mathrm{c}} 16.7$ \\
\hline Ulocladium & $0.03 \pm 0.03^{\mathrm{a}}$ & 12.5 & $0.00 \pm 0.00^{\mathrm{a}}$ & 0.0 & $0.00 \pm 0.00^{\mathrm{a}}$ & 0.0 & $0.00 \pm 0.00^{\mathrm{a}}$ & 0.0 & $0.00 \pm 0.00^{\mathrm{a}}$ & 0.0 & $0.00 \pm 0.00^{\mathrm{a}} \quad 0.0$ \\
\hline $\begin{array}{l}\text { Stachybotrys } \\
\text { chartarum }\end{array}$ & $0.00 \pm 0.00^{\mathrm{a}}$ & 0.0 & $0.00 \pm 0.00^{\mathrm{a}}$ & 0.0 & $0.00 \pm 0.00^{\mathrm{a}}$ & 0.0 & $0.00 \pm 0.00^{\mathrm{a}}$ & 0.0 & $0.00 \pm 0.00^{\mathrm{a}}$ & 0.0 & $0.00 \pm 0.00^{\mathrm{a}} \quad 0.0$ \\
\hline Verticillium & & & & & & & & & & & \\
\hline tenerum & $0.00 \pm 0.00^{\mathrm{a}}$ & 0.0 & $0.13 \pm 0.13^{\mathrm{a}}$ & 16.7 & $0.00 \pm 0.00^{\mathrm{a}}$ & 0.0 & $0.00 \pm 0.00^{\mathrm{a}}$ & 0.0 & $0.03 \pm 0.03^{\mathrm{a}}$ & 12.5 & $0.00 \pm 0.00^{\mathrm{a}} \quad 0.0$ \\
\hline Sterile & & & & & & & & & & & \\
\hline mycelium & $0.03 \pm 0.03^{\mathrm{a}}$ & 12.5 & $0.04 \pm 0.04^{\mathrm{a}}$ & 16.7 & $0.04 \pm 0.04^{\mathrm{a}}$ & 12.5 & $0.04 \pm 0.04^{\mathrm{a}}$ & 16.7 & $0.00 \pm 0.00^{\mathrm{a}}$ & 0.0 & $0.04 \pm 0.04^{\mathrm{a}} 16.7$ \\
\hline Unidentified & $0.34 \pm 0.18^{\mathrm{a}}$ & 50.0 & $0.04 \pm 0.00^{\mathrm{a}}$ & 0.0 & $0.00 \pm 0.00^{\mathrm{a}}$ & 0.0 & $0.00 \pm 0.00^{\mathrm{a}}$ & 0.0 & $0.09 \pm 0.07^{\mathrm{a}}$ & 25.0 & $0.04 \pm 0.04^{\mathrm{a}} 16.7$ \\
\hline Total & $3.47 \pm 1.05^{b}$ & & $0.42 \pm 0.19^{\mathrm{c}}$ & & $0.16 \pm 0.07^{\mathrm{c}}$ & & $0.12 \pm 0.06^{\mathrm{c}}$ & & $0.51 \pm 0.12^{\mathrm{c}}$ & & $0.24 \pm 0.12^{\mathrm{c}}$ \\
\hline
\end{tabular}

a data are shown as mean values \pm standard error;

${ }^{\mathrm{b}}$ different letters in row indicate significant differences $(P<0.01)$ among examined samples $(\mathrm{n})$.

TABLE IV: CONCENTRATION AND RANGE OF CULTURABLE FUNGI (CFU M ${ }^{-3}$ ) IN INDOOR AIR OF TEST BUILDINGS AND INDOOR/OUTDOOR (I/O) RATIO

\begin{tabular}{|c|c|c|c|c|c|c|c|c|c|c|}
\hline \multirow[b]{2}{*}{ Fungi } & \multicolumn{2}{|l|}{ AER } & \multicolumn{2}{|c|}{ CER } & \multicolumn{2}{|l|}{ EXP } & \multicolumn{2}{|c|}{ LOG } & \multicolumn{2}{|c|}{ PLY } \\
\hline & concentration $^{a b}$ & range & concentration & range & concentration & range & concentration & range & concentration & range \\
\hline Alternaria & $1.4 \pm 0.9^{\mathrm{a}}$ & $0-14$ & $0.0 \pm 0.0^{\mathrm{a}}$ & 0 & $0.5 \pm 0.5^{\mathrm{a}}$ & $0-14$ & $0.3 \pm 0.3^{\mathrm{a}}$ & $0-7$ & $0.3 \pm 0.3^{\mathrm{a}}$ & $0-7$ \\
\hline Aspergillus & $22.2 \pm 9.4^{\mathrm{a}}$ & $0-96$ & $0.6 \pm 0.3^{c}$ & $0-7$ & $3.4 \pm 1.4^{b}$ & $0-27$ & $0.3 \pm 0.3^{c}$ & $0-7$ & $0.5 \pm 0.3^{c}$ & $0-7$ \\
\hline Aureobasidium & $1.2 \pm 0.7^{\mathrm{a}}$ & $0-14$ & $2.1 \pm 0.6^{\mathrm{a}}$ & $0-14$ & $1.1 \pm 0.7^{\mathrm{a}}$ & $0-14$ & $1.1 \pm 0.9^{\mathrm{a}}$ & $0-14$ & $1.1 \pm 0.7^{\mathrm{a}}$ & $0-14$ \\
\hline Cladosporium & $19.0 \pm 5.8^{a}$ & $0-69$ & $20.4 \pm 5.5^{\mathrm{a}}$ & $0-69$ & $15.1 \pm 3.7^{\mathrm{a}}$ & $0-69$ & $15.4 \pm 4.9^{\mathrm{a}}$ & $0-69$ & $17.1 \pm 6.0^{\mathrm{a}}$ & $0-69$ \\
\hline Geomyces & $0.3 \pm 0.3^{\mathrm{a}}$ & $0-7$ & $0.0 \pm 0.0^{\mathrm{a}}$ & 0 & $0.5 \pm 0.5^{\mathrm{a}}$ & $0-7$ & $0.0 \pm 0.0^{\mathrm{a}}$ & 0 & $0.0 \pm 0.0^{\mathrm{a}}$ & 0 \\
\hline Geotrichum & $0.6 \pm 0.6^{\mathrm{a}}$ & $0-7$ & $0.5 \pm 0.5^{\mathrm{a}}$ & $0-7$ & $1.6 \pm 0.7^{\mathrm{a}}$ & $0-14$ & $0.3 \pm 0.3^{\mathrm{a}}$ & $0-7$ & $0.0 \pm 0.0^{\mathrm{a}}$ & 0 \\
\hline Gonytrichum & $1.8 \pm 1.8^{\mathrm{a}}$ & $0-14$ & $0.0 \pm 0.0^{\mathrm{a}}$ & 0 & $0.0 \pm 0.0^{\mathrm{a}}$ & 0 & $0.0 \pm 0.0^{\mathrm{a}}$ & 0 & $0.0 \pm 0.0^{\mathrm{a}}$ & 0 \\
\hline Penicillium & $8.9 \pm 4.8^{\mathrm{a}}$ & $0-27$ & $4.4 \pm 0.8^{a}$ & $0-21$ & $7.8 \pm 3.3^{\mathrm{a}}$ & $0-27$ & $2.1 \pm 0.7^{b}$ & $0-14$ & $3.2 \pm 1.2^{\mathrm{ab}}$ & $0-14$ \\
\hline Zygorhynchus & $0.6 \pm 0.6^{\mathrm{a}}$ & $0-7$ & $0.9 \pm 0.9^{\mathrm{a}}$ & $0-14$ & $0.5 \pm 0.5^{\mathrm{a}}$ & $0-7$ & $0.5 \pm 0.5^{\mathrm{a}}$ & $0-7$ & $0.5 \pm 0.5^{\mathrm{a}}$ & $0-14$ \\
\hline Yeasts & $4.3 \pm 3.0^{\mathrm{a}}$ & $0-27$ & $3.5 \pm 1.5^{\mathrm{a}}$ & $0-14$ & $5.6 \pm 1.8^{\mathrm{a}}$ & $0-27$ & $1.3 \pm 0.5^{\mathrm{a}}$ & $0-14$ & $1.5 \pm 0.9^{\mathrm{a}}$ & $0-14$ \\
\hline Sterile mycelium & $7.5 \pm 2.7^{\mathrm{a}}$ & $0-27$ & $4.3 \pm 1.2^{\mathrm{a}}$ & $0-21$ & $5.4 \pm 1.8^{\mathrm{a}}$ & $0-27$ & $3.4 \pm 2.8^{\mathrm{a}}$ & $0-27$ & $2.0 \pm 0.7^{\mathrm{a}}$ & $0-14$ \\
\hline Others ${ }^{\mathrm{c}}$ & $15.5 \pm 4.1^{\mathrm{a}}$ & $0-41$ & $14.0 \pm 6.00^{\mathrm{a}}$ & $0-55$ & $12.1 \pm 9.1^{\mathrm{a}}$ & $0-82$ & $5.7 \pm 3.4^{\mathrm{a}}$ & $0-41$ & $7.1 \pm 4.8^{\mathrm{a}}$ & $0-55$ \\
\hline
\end{tabular}




\begin{tabular}{|c|c|c|c|c|c|c|c|c|c|c|}
\hline Total & $83.2 \pm 33.6^{\mathrm{a}}$ & $41-178$ & $50.7 \pm 16.2^{\mathrm{ab}}$ & $7-117$ & $53.6 \pm 16.7^{\text {ab }}$ & $14-165$ & $30.4 \pm 12.8^{b}$ & $0-96$ & $33.3 \pm 10.2^{b}$ & $7-105$ \\
\hline I/O air & 0.12 & & 0.05 & & 0.06 & & 0.03 & & 0.03 & \\
\hline
\end{tabular}

a data are shown as mean values \pm standard error;

$\mathrm{b}$ different letters in row indicate significant differences $(P<0.01)$ among examined air samples $(n=5)$;

${ }^{c}$ fungi identified only once or twice, such as Acrophialophora, Arthrinium, Cirrhomyces, Curvularia, Hormiscium, Leptostroma, Mucor, Neurospora,

Papulaspora, Phoma, Phyllosticta, Polyscytalum, Rhinocladiopsis, Scopulariopsis, Thysanophora etc.

It is usually difficult to determine the threshold concentration level of aeromycoflora between the mouldy and reference houses as these values can vary over a wide range. Obtained data suggested that the determined fungal pollution was low $\left(<100 \mathrm{CFU} \mathrm{m}^{-3}\right)$ in all test buildings. These results may be considered acceptable according to most guidelines [18], [22], [24]. Salonen et al. [18] have advised new standard for assessment of microbial pollution in modern buildings with effective ventilation and excluded influence of outdoor air. They reduced threshold limit and defined that a fungi

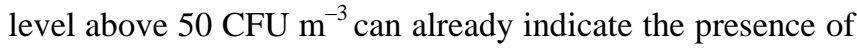
an indoor mould source. This suggestion helps to characterize and explain outcomes of the present study, although it is not completely correct to compare the results obtained with different sampling techniques, i.e. air sampler and sedimentation plates. However, obtained results show that an analysis of air samples alone is insufficient to make in-depth conclusions. Incorporation of surface analysis is essential to get a more complete view of fungal biodiversity in indoor environment. This is in agreement with previously reported studies [11], [25].

\section{CONCLUSIONS}

The results of the present study show that (i) proper ventilation is an indispensable tool to reduce chemical pollution caused by volatile organic compound emissions from building and finishing materials in indoor environment; (ii) presence of any moisture source in building materials (use of mortar, plaster and, in particular, aerated concrete) can cause mould development, and additional care (extra ventilation etc.) must be taken to avoid it; (iii) at favourable conditions plaster may serve as substrate for mould growth immediately after building's completion; (iv) at common indoor temperature increase of RH over $60 \%$ can be sufficient for fungal growth; (v) in rooms with effective ventilation surface samples are more informative than air samples.

\section{ACKNOWLEDGMENT}

Inga Apine would like to thank Dr. Vizma Nikolajeva for her valuable advice and assistance in fungi identification.

\section{REFERENCES}

[1] H. A. A. Khan and M. S. Karuppayil, "Fungal pollution of indoor environments and its management," Saudi J. Biol. Sci., vol. 19, no. 4 , pp. 405-426, Oct. 2012.

[2] F. Haghighat and L. De Bellis, "Material emission rates: Literature review, and the impact of indoor air temperature and relative humidity," Build. Environ., vol. 33, no. 5, pp. 261-277, Sept. 1998.

[3] M. Czajka, and A. Dziewanowska-Pudliszak, "Emission of volatile organic compounds (VOC) from lacquered surfaces," in Management of Indoor Air Quality, M. R. Dudzinska, Ed. London: CRC Press, 2011, pp. 45-54.

[4] M. Tuomainen, A.-L. Pasanen, A. Tuomainen, J. Liesivuori, and P. Juvonen, "Usefulness of the Finnish classification of indoor climate, construction and finishing materials: comparison of indoor climate between two new blocks of flats in Finland," Atmos. Environ., vol. 35, no. 2, pp. 305-313, 2001.

[5] J. Sundell, H. Levin, W. W. Nazaroff et al., "Ventilation rates and health: multidisciplinary review of the scientific literature", Indoor Air, vol. 21, no. 3, pp. 191-204, June 2011.

[6] C. R. Łukaszuk, E. Krajewska-Kułak, and W. Kułak, "Effects of fungal air pollution on human health," Prog. Health Sci., vol. 1, no. 2, pp. 156-164, Dec. 2011.

[7] J. P. S. Cabral, "Can we use indoor fungi as bioindicators of indoor air quality? Historical perspectives and open questions," Sci. Total Environ., vol. 408, no. 20, pp. 4285-4295, Sept. 2010.

[8] O. C. Adan, H. P. Huinink, and M. Bekker, "Water relations of fungi in indoor environments," in Fundamentals of Mold Growth in Indoor Environments and Strategies for Healthy Living, O. C. G. Adan, and R. A. Samson, Eds. Wageningen, The Netherlands: Wageningen Academic Publishers, 2011, pp. 41-65.

[9] E. M. Sterling, A. Arundel, and T. D. Sterling, "Criteria for human exposure to humidity in occupied buildings," ASHRAE Trans., vol. 91, no. 1B, pp. 611-621, Jan. 1985.

[10] O. Seppänen and J. Kurnitski, "Moisture control and ventilation," WHO Guidelines for Indoor Air Quality: Dampness and Mold., 2009, ch. 3, pp. 31-62.

[11] B. Andersen, J. C. Frisvad, I. Søndergaard, I. S. Rasmussen, and L. S. Larsen, "Associations between fungal species and water-damaged building materials," Appl. Environ. Microbiol., vol. 77, no. 12, pp. 4180-4188, Jun 2011

[12] T. Warscheid, "Mold remediation in West-European buildings," in Fundamentals of mold Growth in Indoor Environments and Strategies for Healthy Living, O. C. G. Adan, and R. A. Samson, Eds. Wageningen, The Netherlands: Wageningen Academic Publishers, 2011, pp. 413-433.

[13] A. Jakovics, S. Gendelis, A. Ozolins, and S. Sakipova, "Energy efficiency and sustainability of low energy houses in latvian climate conditions," in Proc. Int. Conf. Energy, Environ., Dev. and Econ., Santorini, Greece, 2014, pp. 109-114.

[14] I. Dimdiṇa, A. Jakovičs, S. Gendelis, and J. Kḷaviņš, "Testing of energy-efficient building envelope materials in natural conditions," in Proc. Int. Conf. on World Sustainable Energy Days, Wels, Austria, 2013, pp. 1-5.

[15] M. Małecka-Adamowicz, W Donderski, and A. Okoniewska, "Evaluation of microbial air quality in a forest recreation park," Pol. J. Environ. Stud., vol. 19, no. 1, pp. 107-113, Jan. 2010.

[16] H. Beguin and N. Nolard, "Mould biodiversity in homes I. Air and surface analysis of 130 dwellings," Aerobiologia, vol. 10, no. 2-3, pp. 157-166, Dec. 1994.

[17] R. A. Samson, J. A. M. P. Houbraken, R. C. Summerbell, B. Flannigan, and J. D. Miller, "Common and important species of fungi and actinomycetes in indoor environments," in Microorganisms in Home and Indoor Work Environments, B. Flannigan, R. A. Samson, and J. D. Miller, Eds. Boca Raton, FL: CRC Press, 2001, ch. 5, pp. 285-473.

[18] H. Salonen, S. Lappalainen, O. Lindroos, R. Harju, and K. Reijula, "Fungi and bacteria in mould-damaged and non-damaged office environments in a subarctic climate," Atmos. Environ., vol. 41, no. 32, pp. 6797-6807, Oct. 2007.

[19] K. F. Nielsen, "Mold growth on building materials. Secondary metabolites, mycotoxins and biomarkers," Ph.D. thesis, BioCentrum-DTU, Technical Univ. of Denmark, Denmark, 2002.

[20] T. A. Lupoli, C. E. Ciaccio, and J. M. Portnoy, "Home and school environmental assessment and remediation," Curr. Allergy Asthma Rep., vol. 9, no. 6, pp. 419-425, Nov. 2009.

[21] D. Haas, J. Habib, J. Luxner, H. Galler, G. Zarfel, R. Schlacher et al., "Comparison of background levels of culturable fungal spore concentrations in indoor and outdoor air in southeastern Austria," Atmos. Environ., vol. 98, pp. 640-647, Dec. 2014.

[22] A. Hyvärinen, M. Vahteristo, T. Meklin, M. Jantunen, A. Nevalainen, and D. Moschandreas, "Temporal and spatial variation of fungal concentrations in indoor air," Aerosol Sci. Technol., vol. 35, no. 2, pp. 688-695, Feb. 2001 
[23] M. Richardson, "The ecology of the Zygomycetes and its impact on environmental exposure," Clin. Microbiol. Infec., vol. 15, pp. 2-9, Oct. 2009.

[24] R. E. Gots, N. J. Layton, and S. W. Pirages, "Indoor health: Background level of fungi," AIHA J., vol. 64, no. 4, pp. 427-438, Jul./Aug. 2003.

[25] T. Verdier, M. Coutand, A. Bertron, and C. Roques, "A review of indoor microbial growth across building materials and sampling and analysis methods," Build. Environ., vol. 80, pp. 136-149, Oct. 2014.

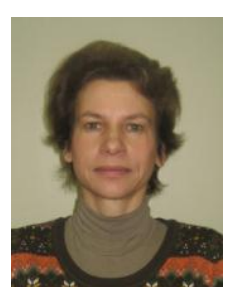

Inga Apine received her M.Sc. degree in biology from University of Latvia in 2000. She has finished her doctoral programme at the same institution in 2008. Currently she is a researcher at the Laboratory of Plant Biology, University of Latvia. Her interests include indoor air pollution caused by fungal contamination and endophytic fungi in plants of genus Rhododendron.

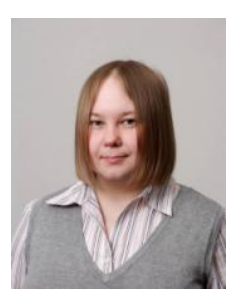

Liana Orola received her Ph.D. degree in chemistry from Riga Technical University. Currently she is a senior researcher at the University of Latvia. Her research interests include environmental and physical chemistry.

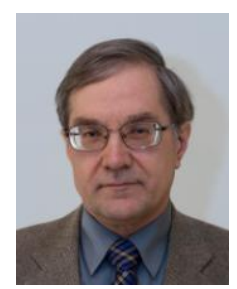

Andris Jakovics is a phys. doctor since 1979 and an assoc. prof. since 2002. Currently he is the head of the Chair of Electrodynamics and Continuum Mechanics at the University of Latvia. His main research interests are related to numerical and experimental investigations of heat and mass transfer processes in several technical applications. 